\title{
Skeptheism: Is Knowledge of God's Existence Possible?
}

\author{
Moti Mizrahi \\ Florida Institute of Technology \\ mmizrahi@fit.edu
}

Forthcoming in European Journal for Philosophy of Religion

\begin{abstract}
In this paper, I sketch an argument for the view that we cannot know (or have good reasons to believe) that God exists. Some call this view "strong agnosticism" but I prefer the term "skeptheism" in order to clearly distinguish between two distinct epistemic attitudes with respect to the existence of God, namely, agnosticism and skepticism. For the skeptheist, we cannot know (or have good reasons to believe) that God exists, since there can be neither conceptual (a priori) nor empirical (a posteriori) evidence for the existence of God.
\end{abstract}

Keywords: agnosticism; atheism; skeptheism; theism

\section{What is skeptheism?}

In this paper, I present an argument in support of the view that some call "strong agnosticism." According to Le Poidevin (2010), for instance, "[strong agnosticism] says that we cannot know whether or not God exists" (emphasis in original). I will use the term "skeptheism" to refer to the view that knowledge of God's existence is unattainable in order to capture what I take to be an important difference in epistemic attitudes about the existence of God, namely, a difference between agnosticism (or suspending judgment) and skepticism. ${ }^{1}$ An agnostic is someone who suspends judgment about the existence of God because he or she thinks that there is no sufficient evidence either for or against the existence of God. But an agnostic is open, in principle, to further evidence that might come to light and make us revise our beliefs about the existence of God. A skeptheist, on the other hand, thinks that no evidence, of any kind, can show that God exists. As far as we are concerned, the existence of God is beyond our ken. In other

\footnotetext{
${ }^{1}$ By "God," I mean a being that, at a minimum, is perfect in terms of power, knowledge, and goodness. In other words, God is supposed to be an omnipotent (all-powerful), omniscient (all-knowing) and omnibenevolent (allgood) being. On this conception of God, see Wierenga (1989, pp. 1-6). For more on the divine attributes, see Everitt (2010). On some puzzles concerning the divine attributes, see Author.
} 
words, agnostics think that knowledge of God's existence is possible, whereas skeptheists think that knowledge of God's existence is impossible. ${ }^{2}$

Skeptheism is also different from atheism, since an atheist thinks that we can know whether or not God exists. According to the atheist, we know (or have good reasons to believe) that God does not exist. 3 But a skeptheist is someone who thinks that, in principle, there is no way for us to find out whether or not God exists. In that respect, a skeptheist is a skeptic about God's existence, whereas an atheist denies God's existence. 4

It is important to note that, although I have distinguished skeptheism from atheism and agnosticism in terms of the possibility of knowing whether or not God exists, the distinction does not turn on the any particular analysis of knowledge. For the same distinction can be articulated in terms of justified belief (i.e., a belief that is based on adequate justification) or reasonable belief (i.e., a belief for which a good reason can be given). That is to say, while theists would say that we have good reasons to believe that God exists, atheists would say that we have good reasons to believe that God does not exist, and agnostics would say that we have good reasons to believe neither that God exists nor that God does not exist, skeptheists would say that no good reasons can be had either for or against the existence of God. Throughout this paper, then, each occurrence of 'knowledge' can be replaced with 'justified belief' and each occurrence of 'know that' is interchangeable with 'justifiably believe that'.

It is also worth noting that skeptheism is clearly different from both skeptical theism and negative theology. Of course, both skeptical theists and negative theologians do not think that God does not exist. Rather, negative theologians, such as Maimonides (1963, p. 482), 5 claim that we cannot justifiably make any positive claims about the nature of God, such as "God is omnipotent," whereas skeptical theists, such as van Inwagen (1995, pp. 85-95), claim that our cognitive limitations are such that we can never fathom God's reasons for allowing evil in this world. ${ }^{6}$ Skeptheists, on the other hand, claim that it is not only God's nature and his reasons for allowing evil that are forever beyond our ken but also God's very existence. Accordingly, Figure 1 depicts the attitudes one can take vis-à-vis the existence of God.

\footnotetext{
${ }^{2}$ Oppy (2006, p. 15) distinguishes between "strong agnosticism," which is "the view that is sustained by the thesis that it is obligatory for reasonable persons to suspend judgment on the question of the existence of an orthodoxly conceived monotheistic God," and "weak agnosticism," which is "the view that is sustained by the thesis that it is permissible for reasonable persons to suspend judgment about on the question of the existence of an orthodoxly conceived monotheistic God" (emphasis in original). Unlike Oppy's weak and strong agnosticism, which are theses about what reasonable persons should (or should not) do, skeptheism (as I understand it here) is a thesis about what we can (or cannot) know (or reasonably believe).

${ }^{3}$ On the distinction between "positive atheism," i.e., to affirm the non-existence of God, and "negative atheism," i.e., to lack a belief that God exists, see Flew (1984, pp. 13-30). On atheism as "the position of not believing that a theistic God exists," see Martin (1990, p. 26).

${ }^{4}$ Cf. Miller (2011, p. 105, footnote 26). According to Miller (2011, p. 99), "Most atheists are error theorists about theists; they claim that theists have genuine beliefs about the existence and nature of a divine being, but as a matter of fact no such divine being exists."

${ }^{5}$ See also Seeskin (2005, p. 89).

${ }^{6}$ For more on skeptical theism, see McBrayer (2010) and the essays collected in Dougherty and McBrayer (2014).
} 
Figure 1. Epistemic attitudes vis-à-vis the existence of God

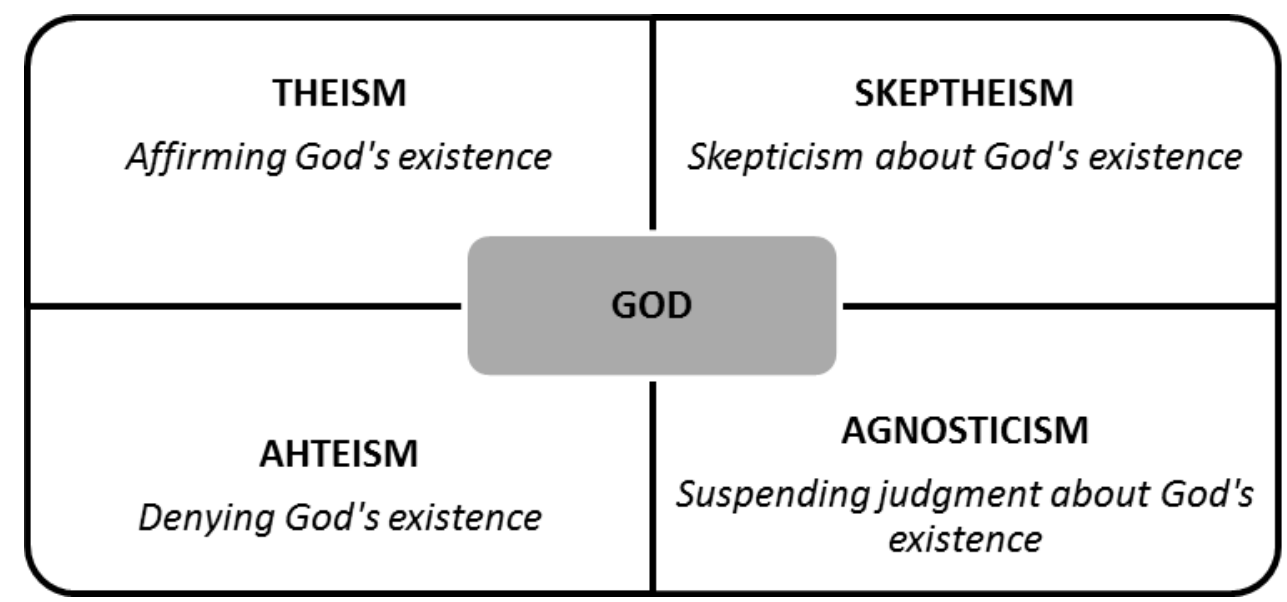

Accordingly, theists, atheists, agnostics, and skeptheists would respond to the question "Do we know whether or not God exist?" as follows:

Theist: We know (or have good reasons to believe) that God exists.

Atheist: We know (or have good reasons to believe) that God does not exist.7

Agnostic: We do not know (or have good reasons to believe) that God exists. ${ }^{8}$

Skeptheist: We cannot know (or have good reasons to believe) that God exists. 9

Note the key difference between the agnostic's response and the skeptheist's response. The former leaves open the possibility that we might come to know whether or not God exists, whereas the latter amounts to denying the possibility of knowing whether or not God exists. Unlike the agnostic, then, the skeptheist is a skeptic about God's existence. ${ }^{10}$

Now that we have a good grasp of what skeptheism is and how it differs from theism, atheism, and agnosticism, we are in a position to see what an argument for skeptheism might look like. In the next section, then, I sketch an argument for skeptheism.

\footnotetext{
${ }^{7}$ Cf. Martin (1990, p. 464) on "positive atheism," i.e., "the belief that there is no god or gods." See also Bullivant (2013, pp. 11-21).

${ }^{8}$ Cf. Kenny (2006, p. 21) on agnosticism, i.e., "the position of one who does not know whether or not there is a God." See also Kenny (2009, pp. 117-124).

${ }^{9}$ A skeptheist, then, is not merely a Pyrrhonist about God's existence, i.e., one who suspends judgment about God's existence, but rather an academic skeptic about God's existence, i.e., one who denies the possibility of knowing that God exists.

${ }^{10}$ On religious belief and skepticism, see Avnur (2011). For a recent argument that knowledge of God is a cognitive achievement, see Bolos (2015).
} 


\section{An argument for skeptheism}

\section{2a. Why the existence of God cannot be known a posteriori}

In this section, I sketch an argument for skeptheism, the skeptical view that knowledge of God's existence is beyond our ken as a matter of principle. ${ }^{11}$ To set the stage for this argument in support of skeptheism, consider what Philo says about the teleological argument in Hume's Dialogues Concerning Natural Religion (1779):

A very small part of this great system, during a very short time, is very imperfectly discovered to us; and do we thence pronounce decisively concerning the origin of the whole?

Admirable conclusion! Stone, wood, brick, iron, brass, have not, at this time, in this minute globe of earth, an order or arrangement without human art and contrivance: therefore the universe could not originally attain its order and arrangement, without something similar to human art. But is a part of nature a rule for another part very wide of the former? Is it a rule for the whole? Is a very small part a rule for the universe? Is nature in one situation, a certain rule for nature in another situation vastly different from the former? (Hume 1907, pp. 4243)

Philo thus objects to the teleological argument by pointing out that we cannot infer that the unobservable cause (i.e., the creator) of the universe is God solely from observable effects. This is so because we do not have the relevant background information that would license such an inference. To see why, consider how the unobservable cause of a viral disease is inferred from its observable effects. In the case of HIV/AIDS, for example, cohorts of patients that exhibit symptoms of HIV infection are tested for the HIV virus and are then compared with control groups of subjects that either exhibit symptoms but do not carry the virus or do not exhibit symptoms but do carry the virus. In other words, several controlled experiments, usually retrospective studies, must be performed before one can reasonably conclude that the unobservable cause of observable effect $E$ is $C$. This sort of experimental reasoning is depicted in Figure 2.

\footnotetext{
${ }^{11}$ I should say that what follows is not intended to be an accurate interpretation of the primary texts cited. I only cite Hume and Gaunilo because the arguments I discuss in this section are inspired by what they say in response to the teleological and ontological arguments, respectively. On Philo's objections against the teleological argument, see Cordry (2011). On the enduring appeal of the teleological argument, see De Cruz (2014).
} 
Figure 2. Experimental reasoning from observable effect $E$ to unobservable cause $C .{ }^{12}$

\begin{tabular}{|l|l|l|}
\hline Case & Antecedent conditions & Effect \\
\hline 1 & $C, X, Y, Z$ & $E$ \\
\hline 2 & $C, X, Y$ & $E$ \\
\hline 3 & $C, X$ & $E$ \\
\hline 4 & $C, Y$ & $E$ \\
\hline 5 & $X, Y, Z$ & No $E$ \\
\hline 6 & $X, Y$ & No $E$ \\
\hline 7 & $X$ & No $E$ \\
\hline 8 & $Y$ & No $E$ \\
\hline
\end{tabular}

For example, the unobservable cause $C$ is the HIV virus, which is always present whenever AIDS symptoms are present but is absent whenever AIDS symptoms are absent.

Now, Philo's point is that, in the case of the universe (the observable effect), we cannot perform controlled experiments, retrospective or otherwise, since there are no cases where the effect is absent. After all, we inhabit a small planet in one solar system which is part of one galaxy out of billions of other galaxies. Even if there are other universes, they are epistemically inaccessible to us. Moreover, for all we know, there are no cases where the unobservable cause (which is supposed to be God) is absent, either. In other words, as far as God and the universe are concerned, we lack the relevant background information that would warrant an inference from observable effects to unobservable cause. If this is correct, then the following argument can be made:

(3.1) We can justifiably infer an unobservable cause from observable effects only if we have the relevant background information about the cause and the effects.

(3.2) In the case of God and the universe, we cannot have the relevant background information about the cause and the effects.

Therefore,

(3.3) We cannot justifiably infer that God is the unobservable cause of the universe from observable effects alone.

Note that this argument is neither an argument for atheism nor an argument for agnosticism. That is to say, this argument does not show that one should deny the existence of God. Nor does it show that one should suspend judgment about the existence of God. Rather, this argument shows that we cannot infer the existence of God from a certain kind of evidence, namely, empirical evidence. In other words, this argument shows that there can be no empirical or a posteriori knowledge of God's

12 Adapted from Salmon (2013, p. 174). Compare to Mill's joint method of agreement and difference for establishing causal claims. 
existence. As such, this argument is an argument for skeptheism, in particular, skepticism about a posteriori or empirical knowledge of God's existence. ${ }^{13}$

To be clear, my argument here is not "One argument for the existence of God from empirical evidence (e.g., biological design, fine-tuning, miracles, moral facts, religious experience, etc.) fails; therefore, all empirical arguments for the existence of God fail." Rather, my argument is that the existence of God cannot be known $a$ posteriori because a necessary condition for arguing for the existence of God on the basis of empirical evidence cannot be fulfilled, namely, the condition of having the relevant background information that licenses an inference from observable effects (e.g., biological design, fine-tuning, miracles, moral facts, religious experience, etc.) to unobservable cause (namely, God).

To this it might be objected that 'God exists' can be known (or justifiably believed) to be true $a$ posteriori on the basis of religious experience and that such experiences count as empirical evidence for the existence of God without relying on any inferences from observable effects to unobservable cause. ${ }^{14}$ For example, Tucker (2011, p. 64) argues that religious experience counts as evidence for God's existence on the basis of Phenomenal Conservatism (PC), according to which "a subject $[S]$ has evidence for $\mathrm{P}$ if it seems [to $S$ ] that $\mathrm{P}$."15 If $\mathrm{PC}$ is true, and $S$ has a religious experience where it seems to $S$ as if God exists, then $S$ has evidence for God's existence, or so Tucker (2011) argues. ${ }^{16}$

Tucker (2011, pp. 65-67) goes on to say that the evidence for God's existence provided by these seemings (namely, religious experiences) will usually be undefeated by other evidence. ${ }^{17}$ But I think that this is mistaken. Here is why. For religious experience to count as empirical evidence for God's existence there must be good reasons to believe that God is indeed the unobservable cause of such experiences. The problem is that there are other potential causes for religious experiences, such as psychotropic drugs ${ }^{18}$ and weak magnetic fields. ${ }^{19}$ So God is not the only potential cause of religious experiences. There are other potential causes. In that case, the question is which of these potential causes is the one that actually causes religious experience? In

\footnotetext{
${ }^{13}$ It is worth noting that this argument for skepticism about empirical knowledge of God's existence does not depend on any Humean skepticism about causation. For the argument does not assume that we cannot infer an unobservable cause from observable effects. Rather, premise (3.1) says that we can justifiably do so just in case we have the relevant background information, so that we do not mistake mere coincidences for causal relations. As far as God and the universe are concerned, however, we do not have the relevant background information.

${ }^{14}$ Various versions of the argument from religious experience can be found in Swinburne (1979), Alston (1991), and Plantinga (2000). See also Zagzebski (2011).

${ }^{15}$ For a useful review of the literature on Phenomenal Conservatism, see Moretti (forthcoming). For objections against Phenomenal Conservatism, see Author.

${ }^{16}$ It is important to note that, as far as Phenomenal Conservatism is concerned, beliefs that are based on seemings are different from beliefs that are based on faith. See Huemer (2011, pp. 1-13). On faith, see Howard-Snyder (2013, pp. 357-372) and Kvanvig (2013).

${ }^{17}$ Cf. Smith (2014).

${ }^{18}$ See Griffiths et al (2006), Griffiths et al (2008), Griffiths et al (2011), MacLean et al (2011).

${ }^{19}$ See Derr and Persinger (1989) and Booth and Persinger (2009). For a critique of these results, see Granqvist et al (2005). For a reply, see Persinger and Koren (2005).
} 
other words, of these potential explanations for the phenomenon of religious experience, which is the best one?

To answer this question, then, we would have to rely on inferences from observable effects (in this case, religious experiences) to cause (in this case, a supernatural cause, such as God, or a natural cause, such as psychotropic drugs or weak magnetic fields). This is a general point about the use of natural phenomena as empirical evidence for God's existence. That is to say, for any natural phenomenon $P$, such as religious experience, apparently miraculous events, design (either biological or cosmic), and the like, $P$ is empirical evidence for God's existence just in case there are good reasons to believe that God is indeed the unobservable cause of $P$. If there are alternative explanations for $P$, then $P$ is empirical evidence for God's existence just in case the God explanation can be shown to be better than the other explanations. ${ }^{20}$ Showing that the God explanation is the best explanation among competing explanations for $P$, however, requires making inferences from observable effects $(P)$ to unobservable cause (God), i.e., showing that God, but not the other causes, is the most likely cause of the phenomenon in question. ${ }^{21}$ This is why (3.3) applies to any alleged $a$ posteriori or empirical evidence for God's existence.

If this is correct, then, contrary to Tucker's claim that religious experience is typically undefeated evidence for God's existence, there are such defeaters. The fact that there are natural explanations for religious experiences (e.g., in terms of psychotropic drugs or weak magnetic fields) defeats the claim that such experiences are empirical evidence for God's existence, unless it can be shown that God-not natural causes like psychotropic drugs or weak magnetic fields-is the most likely cause of such experiences. In order to show that, however, one would have to rely on inferences from observable effects (religious experience) to unobservable cause (God). For this reason, (3.3) applies to any alleged a posteriori or empirical evidence for God's existence, including religious experience.

In other words, there are at least two competing explanations for religious experience and each explanation can be supported by an Inference to the Best Explanation (IBE). ${ }^{22}$ The first explanation is a supernatural one in terms of a supernatural entity like God:

1. Some people have religious experiences.

\footnotetext{
${ }^{20}$ This is why the multiverse hypothesis is a common objection against the fine-tuning argument. The multiverse hypothesis provides an alternative explanation for fine-tuning, an explanation that does not appeal to a supernatural designer, and thus fine-tuning does not uniquely support the design hypothesis. See Manson (2009, pp. 274-275). Cf. Juhl (2006) and Roberts (2012). See also Author and Harker (2012).

${ }^{21}$ Note that, even if we have good reasons to believe that natural explanations are not good enough to account for a given natural phenomenon, all that follows from that is that a supernatural explanation may be the best one. But a supernatural explanation for a natural phenomenon is a far cry from God. After all, God is supposed to be, at a minimum, an omnipotent, omniscient, and morally perfect being. As Philo points out in Hume's Dialogues Concerning Natural Religion, these divine attributes cannot be inferred from phenomena like design in any straightforward way. The same point applies to other natural phenomena, such as religious experience, and the like. Cf. Author.

${ }^{22}$ On the structure of IBE, see Psillos (2007).
} 
2. The best explanation for (1) is that these experiences are caused by a supernatural entity.

3. No other hypothesis explains (1) as well as the supernatural explanation does.

Therefore,

4. Religious experiences are probably caused by a supernatural entity.

Of course, if the conclusion of this IBE is true, then that would be a good reason to believe that a supernatural entity exists. ${ }^{23}$ The second explanation is a natural one in terms of natural entities like psychotropic drugs or weak magnetic fields:

1. Some people have religious experiences.

2. The best explanation for (1) is that these experiences are caused by natural entities (e.g., psychotropic drugs or weak magnetic fields).

3. No other hypothesis explains (1) as well as the natural explanation does.

Therefore,

4. Religious experiences are probably caused by natural entities (e.g., psychotropic drugs or weak magnetic fields).

If the IBE for the natural explanation is cogent, then it counts as an undercutting defeater ${ }^{24}$ against the supernatural explanation for religious experience. More precisely, the alleged evidential connection between "religious experience" and "supernatural cause" is undercut by the fact that religious experiences can be explained in terms of natural causes, such as psychotropic drugs and weak magnetic fields. For this reason, again, (3.3) applies to any alleged a posteriori or empirical evidence for God's existence, including religious experience.

In fact, it may be argued that, when judged relative to generally accepted criteria of selection, the natural explanation in terms of natural entities (like psychotropic drugs or weak magnetic fields) is better than the supernatural explanation in terms of a supernatural entity (like God). Philosophers have offered the following key criteria for selecting between competing explanations (Mizrahi 2012, p. 134):

Unification: As a general rule of thumb, choose the explanation that explains the most and leaves the least unexplained things (see, e.g., Kitcher 1981).

Coherence: As a general rule of thumb, choose the explanation that is consistent with background knowledge (see, e.g., Kosso 1992).

\footnotetext{
${ }^{23}$ Though, again, it may be a supernatural being other than God. For even if the best explanation for religious experience is a supernatural one, it doesn't necessarily follow that the supernatural entity is God. After all, God is supposed to be, at a minimum, an omnipotent, omniscient, and morally perfect being. The supernatural entity that is responsible for religious experience may be powerful enough to cause religious experiences, but not all-powerful. Moreover, why should there be one supernatural entity rather than some or many? As Philo points out in Hume's Dialogues Concerning Natural Religion, the divine attributes cannot be inferred from natural phenomena like design in any straightforward way. The same point applies to other natural phenomena, such as religious experience, and the like. Cf. Author.

${ }^{24}$ Pollock and Cruz (1999, p. 196).
} 
Simplicity: As a general rule of thumb, choose the least complicated explanation, i.e., the one that posits the least causal sequences and entities, and that goes beyond the evidence the least (see, e.g., Sober 1988, 1994, and 1998).

Testability: As a general rule of thumb, choose the explanation that yields independently testable predictions (see, e.g., Zahar 1973, Kitcher 1983, and Leplin 1997).

In terms of unification, the natural (psychotropic drugs or weak magnetic fields) and the supernatural (God) explanations seem to account for the phenomena of religious experience equally well. However, the supernatural explanation raises many unanswered questions that the natural explanation does not. Some of these unanswered questions are the following: Why does God make some people have religious experiences but not others? Many people never have religious experiences. Why is that? Is religious experience the best way for God to make his existence apparent to humans? Being omnipotent and omniscient, God could find a better way to make his existent apparent to humans. After all, "the concept [of religious experience] is vague, and the multiplicity of kinds of experiences that fall under it makes it difficult to capture in any general account" (Webb 2011). Yandell (1993, pp. 25-32) divides religious experiences by the content of the experiences as follows: monotheistic, nirvanic (Buddhism), kevalic (Jainism), moksha (Hinduism), and nature experiences. Why such diversity?

In terms of coherence, the natural explanation is more consistent with our background knowledge than the supernatural explanation is. As far as supernatural entities are concerned, our background knowledge is quite limited compared to what we know about ourselves and the sorts of effects certain drugs can have on us.

In terms of simplicity, the supernatural explanation postulates the existence of a being that is different in kind from anything else in the universe, whereas the natural explanation says that the causes of religious experience are of the same kind as everything else in nature. So the supernatural explanation postulates the existence of a kind of entity that is not quite consistent with our background knowledge. In general, if "entities [especially unobservable ones] should not be multiplied beyond necessity," then the natural explanation is the simpler one.

Finally, and more importantly, in terms of testability, there does not seem to be an independent way to test the supernatural explanation. To choose between these two competing explanations, we need a way to test them independently of the explanandum (i.e., religious experience). One might think that there is no way to test the supernatural explanation, even in principle, given that it postulates the existence of a supernatural entity, and thus it goes beyond the scope of scientific inquiry, which deals with the natural, not the supernatural. Be that as it may, there does not seem to be a way to test the supernatural explanation independently the explanandum (i.e., religious experience).

On the other hand, the natural explanation makes at least one prediction that can be tested independently of the explanandum. If the natural explanation is true, then religious experiences can be induced on demand by using psychotropic drugs or weak 
magnetic fields. As the aforementioned studies show (see footnotes 16 and 17), this is in fact the case.

For these reasons, the natural explanation not only undercuts the alleged evidential connection between "religious experience" and "supernatural entity" but it also outperforms the supernatural explanation when the two are evaluated in terms of theoretical desiderata, such as unification, coherence, simplicity, and testability. All of this shows that (3.3) applies to any alleged a posteriori or empirical evidence for God's existence (e.g., biological design, fine-tuning, miracles, moral facts, religious experience, etc.). ${ }^{25}$

\section{2b. Why the existence of God cannot be known a priori}

Now, to set the stage for the second part of the argument for skeptheism, consider Gaunilo's objection against St. Anselm's ontological argument: ${ }^{26}$

Now, if someone should tell me that there is such an island, I should easily understand his words, in which there is no difficulty, but suppose that he went on to say, as if by a logical inference: 'You can no longer doubt that this island which is more excellent than all lands exists somewhere, since you have no doubt that it is in your understanding. And since it is more excellent not to be in the understanding alone, but to exist both in the understanding and in reality, for this reason it must exist. For if it does not exist, any land which really exists will be more excellent than it; and so the island already understood by you to be more excellent will not be more excellent.

If a man should try to prove to me by such reasoning that this island truly exists, and that its existence should no longer be doubted, either I should believe that he was jesting, or I know not which I ought to regard as the greater fool: myself, supposing that I should allow this proof; or him, if he should suppose that he had established with any certainty the existence of this island (Gaunilo 1962, p. 158). ${ }^{27}$

Accordingly, Gaunilo objects that, by using St. Anselm's reasoning, one can prove the existence of the perfect island, or any other "perfect thing," for that matter. Gaunilo's objection can be expressed informally by saying that one cannot define things into existence. If defining God as "that than which nothing greater can be conceived" shows that God exists, then defining the perfect island as "that island than which no greater island can be conceived" shows that the perfect island exist. That is, using the following argument schema, one can "indirectly prove" the existence of anything whatsoever:

\footnotetext{
${ }^{25}$ On moral arguments for the existence of God, see Ritchie (2012). Such arguments are often construed as IBEs. For instance, in chapter 7 of Ritchie (2012), one can find an IBE from moral facts to the existence of God that goes roughly like this: there are moral facts; the best explanation for the existence of moral facts is that God exists; therefore, God exists. Putting aside the debate about moral realism, this IBE is strong only if the existence of God can be shown to be a better explanation for moral facts (assuming there are such facts) than alternative explanations. ${ }^{26}$ See footnote 9. For a recent reconstruction of the ontological argument, see Matthews and Rudder Baker (2010). On why the Anselmian notion of God is incoherent, see Bohn (2012). Cf. Author. On Spinoza's version of the ontological argument, see Lin (2007).

${ }^{27}$ See also Author.
} 
1. $X$ does not exist. [assumption for reductio]

2. $X$ is perfect. [definition]

3. If $X$ does not exist, then $X$ is not perfect. [from the "Existence in reality is greater than existence in the understanding alone" principle $\left.{ }^{28}\right]$

4. $\therefore X$ is not perfect. [from (1) \& (3)]

5. $\therefore X$ is perfect and $X$ is not perfect. [from (2) \& (4)]

6. $\therefore$ It is not the case that $X$ does not exist. [from (1) \& (5)]

The same problem afflicts the concept of God as a necessary being, which is motivated by perfect-being theology (Bohn 2012). That is, using the following argument schema, one can "indirectly prove" the existence of anything whatsoever:

1. $X$ does not exist. [assumption for reductio]

2. $X$ is a necessary being. [definition]

3. If $X$ is a necessary being, then $X$ cannot fail to exist.

4. $\therefore X$ cannot fail to exist. [from (2) \& (3)]

5. $\therefore X$ does not exist and $X$ cannot fail to exist. [from (1) \& (4)]

6. $\therefore$ It is not the case that $X$ does not exist. [from (1) \& (5)]

If this is correct, then the following argument can be made:

(2.1) We can justifiably infer the existence of something from its definition or conception alone only if the definition or conception in question does not allow us to infer the existence of anything whatsoever.

(2.2) Definitions or conceptions of God as "a perfect being," "a necessary being," or as "that than which nothing greater can be conceived" allow us to infer the existence of anything whatsoever.

Therefore,

(2.3) We cannot justifiably infer the existence of God from definitions or conceptions alone.

Like the argument that shows there can be no a posteriori knowledge of God's existence, this argument is not an argument for atheism. That is, this argument does not show that one should deny the existence of God. Nor does it show that one should suspend judgment about the existence of God. Rather, this argument shows that we cannot infer the existence of God from a certain kind of evidence, namely, definitions or conceptions of God. In other words, this argument shows that there can be no conceptual or a priori knowledge of the existence of God. As such, this argument is an argument for skeptheism, in particular, skepticism about conceptual or a priori knowledge of God's existence.

To be clear, my argument here is not "One argument for the existence of God from conceptual evidence (e.g., perfect or necessary being conceptions of God) fails; therefore, all conceptual arguments for the existence of God fail." Rather, my argument is that the existence of God cannot be known a priori because a necessary condition for

\footnotetext{
${ }^{28}$ See Plantinga (1998, p. 52).
} 
arguing for the existence of God on the basis of conceptual evidence cannot be fulfilled, namely, the condition of having a definition or conception that is neither ad hoc nor too broad as to allow us to infer the existence of anything whatsoever.

\section{2c. Why the existence of God cannot be known}

With these two arguments in hand, namely, the argument that shows that there can be no empirical or a posteriori knowledge of God's existence and the argument that shows that there can be no conceptual or a priori knowledge of God's existence, we can now combine them together into a master argument for skeptheism as follows:

A master argument for skeptheism in terms of knowledge (or justified belief)

(1) The proposition 'God exists' can be known (or justifiably believed) to be true either a priori or a posteriori.

(2) The proposition 'God exists' cannot be known (or justifiably believed) to be true a priori. [from (2.3)]

(3) The proposition 'God exists' cannot be known (or justifiably believed) to be true a posteriori. [from (3.3)]

Therefore,

(4) The proposition 'God exists' cannot be known (or justifiably believed) to be true.

For present purposes, I take it that premise (1) is uncontroversial, since a proposition can be known (or justifiably believed) to be true either by experience (a posteriori) or independently of experience ( $a$ priori). ${ }^{29}$ Now, the aforementioned argument from premises (2.1) and (2.2) to conclusion (2.3) supports premise (2) of the master argument for skeptheism because it shows that there can be no conceptual or a priori knowledge of God's existence. The aforementioned argument from premises (3.1) and (3.2) to conclusion (3.3) supports premise (3) of the master argument for skeptheism because it shows that there can be no empirical or a posteriori knowledge of God's existence. Now, since a priori and a posteriori exhaust all ways of knowing that a proposition is true, it follows that the proposition 'God exists' cannot be known (or justifiably believed), which is precisely the view I have labeled "skeptheism."

Again, note that the master argument is neither an argument for atheism nor an argument for agnosticism. It is not an argument for atheism because it does not purport to show that we should deny the existence of God. It is not an argument for agnosticism because it does not purport to show that we should suspend judgment with respect to

\footnotetext{
${ }^{29}$ Of course, to say that the proposition 'God exists' can be known to be true neither a priori nor a posteriori is not to say that all arguments for the existence of God ever made were either a priori or a posteriori. The former is an epistemological claim, whereas the latter is a historical claim. For a division of arguments for the existence of God into a priori and a posteriori arguments, however, see Richards (2000, p. 11), Palmer (2001, p. 2), Nagasawa (2011, p. 11) and Rea and Pojman (2014, p. 153). In that respect, it is also worth noting that some arguments for the existence of God may be mixed arguments, i.e., arguments that appeal to both conceptual and empirical evidence. For example, in their "New Cosmological Argument," Gale and Pruss (1999) appeal to the concept of a necessary being as well as to the Principle of Sufficient Reason.
} 
the existence of God. Instead, the master argument shows that knowledge of God's existence is in principle beyond our ken. In that respect, it is an argument for skeptheism.

As I have pointed out in Section 1, although I have distinguished skeptheism from atheism and agnosticism in terms of the possibility of knowing whether or not God exists, the distinction does not turn on any particular analysis of knowledge. For those who are worried about the master argument for skeptheism being tainted by some implicit analysis of knowledge, however, here is a version of the master argument for skeptheism in terms of evidence rather than knowledge:

A master argument for skeptheism in terms of evidence

$\left(1^{*}\right)$ Either conceptual (a priori) or empirical (a posteriori) evidence can be adduced in support of the proposition 'God exists'.

$\left(2^{*}\right)$ No conceptual (a priori) evidence can be adduced in support of the proposition 'God exists'. [from (2.3)]

$\left(3^{*}\right)$ No empirical (a posteriori) evidence can be adduced in support of the proposition 'God exists'. [from (3.3)]

Therefore,

(4*) No evidence (of any kind) can be adduced in support of the proposition 'God exists'.

As in the case of the previous version of the master argument for skeptheism (i.e., the master argument in terms of knowledge), I take it that premise ( $\left.1^{*}\right)$ is uncontroversial, since a proposition can be supported either by empirical ( $a$ posteriori) evidence or by non-empirical (a priori) evidence. As before, the aforementioned argument from premises (2.1) and (2.2) to conclusion (2.3) supports premise $\left(2^{*}\right)$ of this version of the master argument for skeptheism because it shows that there can be no conceptual or $a$ priori evidence in support of God's existence. The aforementioned argument from premises (3.1) and (3.2) to conclusion (3.3) supports premise $\left(3^{*}\right)$ of this version of the master argument for skeptheism because it shows that there can be no empirical or $a$ posteriori evidence in support of God's existence. Now, since conceptual (a priori) and empirical (a posteriori) exhaust all kinds of evidence that can be adduced in support of a proposition, it follows that there can be no evidence (of any kind) for the proposition 'God exists', which is precisely the view I have labeled "skeptheism."

Accordingly, theists, atheists, agnostics, and skeptheists would respond to the question "Do we have any evidence for or against the existence of God?" as follows:

Theist: We have some evidence (or good reasons to believe) that God exists.

Atheist: We have some evidence (or good reasons to believe) that God does not exist. 
Agnostic: We do not have evidence (or good reasons to believe) that God exists. ${ }^{30}$

Skeptheist: We cannot have any evidence (or good reasons to believe) that God exists.

Note the key difference between the agnostic's response and the skeptheist's response. The former leaves open the possibility that there might be evidence (good reasons) for or against the existence of God, whereas the latter amounts to saying that no evidence whatsoever can be had either for or against the existence of God.

In closing, it is perhaps worth mentioning that skeptheism is compatible with the existence of God. That is to say, it could be the case that God does exist but we can never know (or have any good reasons to believe) that God exists. In other words, skeptheism is an epistemic attitude one has about the existence of God. It is an attitude of total skepticism about the existence of God (i.e., that knowledge of God's existence is impossible) rather than merely suspension of judgment, which may be temporary. Of course, if we cannot know (or have good reasons to believe) that God exists, then it follows that we do not know (or have good reasons to believe) that God exists.

\section{Conclusion}

My aim in this paper has been to advance an argument for the view that we can never know (or have good reasons to believe) that God exists. If this argument is sound, then the proposition 'God exists' can be known (or justifiably believed) to be true neither conceptually (a priori) nor empirically (a posteriori). I prefer to call this view "skeptheism" rather than "strong agnosticism" to capture a difference in epistemic attitudes, namely, between agnosticism (i.e., suspension of judgment) and total skepticism. For skeptheists, then, the proper attitude to take with respect to the existence of God is neither denial (i.e., we know that God does not exist), as atheists would have it, nor suspension of judgment (i.e., we do not know whether or not God exists), as agnostics would have it, but skepticism (i.e., we cannot know whether or not God exists). For skeptheists, there is no way to know (or have good reasons to believe) that God exists.

\footnotetext{
${ }^{30}$ Alternatively, agnostics might claim that there is no compelling evidence either for or against the existence of God. In other words, the available evidence for and the available evidence against the existence of God are equally convincing, or equally unconvincing, and thus we should suspend judgment until further evidence comes to light. Cf. Oppy (2006, p. 15) on strong versus weak agnosticism.
} 


\section{References}

Alston, W. P. (1991). Perceiving God. Ithaca: Cornell University Press.

Avnur, Y. (2011). In defense of secular belief. In J. L. Kvanvig (ed.), Oxford Studies in Philosophy of Religion Vol. IV (pp. 2-20). Oxford: Clarendon Press.

Bohn, E. D. (2012). Anselmian theism and indefinitely extensible perfection. The Philosophical Quarterly 62: 671-683.

Bolos, A. (2015). Is knowledge of God a cognitive achievement? Ratio.

DOI: $10.1111 /$ rati.12090.

Booth, J. N. and Persinger, M. A. (2009). Discrete shifts within the theta band between the frontal and parietal regions of the right hemisphere and the experiences of a sensed presence. The Journal of Neuropsychiatry and Clinical Neuroscience 21: 279-283.

Bullivant, S. (2013). Defining 'atheism'. In S. Bullivant and M. Ruse (eds.), The Oxford Handbook of Atheism (pp. 11-21). Oxford: Oxford University Press.

Cordry, B. (2011). A more dangerous enemy? Philo's 'confession' and Hume's soft atheism. International Journal for Philosophy of Religion 70: 61-83.

De Cruz, H. (2014). The enduring appeal of natural theological arguments. Philosophy Compass 9: 145-153.

Derr J. S. and Persinger, M. A. (1989). Geophysical variables and behavior: LIV. Zeitoun (Egypt) apparitions of the Virgin Mary as tectonic strain-induced luminosities.

Perceptual and Motor Skills 68: 123-128.

Dougherty, T. and McBrayer, J. P. (Eds.). (2014). Skeptical Theism: New Essays. New York: Oxford University Press.

Everitt, N. (2010). The divine attributes. Philosophy Compass 5: 78-90.

Flew, A. (1984). God, Freedom, and Immortality: A Critical Analysis. Buffalo, NY: Prometheus Books.

Gale, R. M. and Pruss, A. (1999). A new cosmological argument. Religious Studies 35: 461-476.

Gaunilo. (1962). On behalf of the fool. In St. Anselm: Basic Writing. S. N. Deane (trans.). LaSalle: Open Court Publishing Company.

Granqvist, P. Fredrikson, M., Unge, P., Hagenfeldt, A., Valind, S., Larhammar, D., and Larsson, M. (2005). Sensed presence and mystical experiences are predicted by 
suggestibility, not by the application of transcranial weak complex magnetic fields. Neuroscience Letters 379: 1-6.

Griffiths, R. R. Richards, W. A., McCann, U. D. and Jesse, R. (2006). Psilocybin can occasion mystical-type experiences having substantial and sustained personal meaning and spiritual significance. Psychopharmacology (Berl) 187: 268-283.

Griffiths, R. R. Richards, W. A., Johnson, M. W., McCann, U. D., and Jesse, R. (2008). Mystical-type experiences occasioned by psilocybin mediate the attribution of personal meaning and spiritual significance 14 months later. Psychopharmacology (Berl) 22: 621-632.

Griffiths, R. R., Richards, W. A., Johnson, M. W., Richards, B. D., McCann, U. D., and Jesse, R. (2011). Psilocybin occasioned mystical-type experiences: immediate and persisting dose-related effects. Psychopharmacology (Berl) 218: 649-665.

Harker, D. (2012). A surprise for Horwich (and some advocates of the fine-tuning argument (which does not include Horwich (as far as I know))). Philosophical Studies 161: 247-261.

Howard-Snyder, D. (2013). Propositional faith: what it is and what it is not. American Philosophical Quarterly 50: 357-372.

Huemer, M. (2011). Phenomenal conservatism and self-defeat: a reply to DePoe. Philosophical Studies 156: 1-13.

Hume, D. (1907). Dialogues Concerning Natural Religion. B. M'Ewen (ed.). London: William Blackwood and Sons.

Juhl, C. (2006). Fine-tuning is not surprising. Analysis 66: 269-275.

Kenny, A. (2006). What I Believe. New York: Continuum.

Kenny, A. (2009). Agnosticism and atheism. In J. Cornwell and M. McGhee (eds.), Philosophers and God: At the Frontiers of Faith and Reason (pp. 117-124). New York: Continuum.

Kitcher, P. (1981). Explanatory unification. Philosophy of Science 48: 507-531.

Kitcher, P. (1983). Abusing Science: The Case against Creationism. Cambridge, MA: The MIT Press.

Kosso, P. (1992). Reading the Book of Nature: An Introduction to the Philosophy of Science. New York: Cambridge University Press.

Kvanvig, J. L. (2013). Affective theism and people of faith. Midwest Studies in Philosophy 37: 109-128. 
Leplin, J. (1997). A Novel Defence of Scientific Realism. New York: Oxford University Press.

Le Poidevin, R. (2010). Agnosticism: A Very Short Introduction. New York: Oxford University Press.

Lin, M. (2007). Spinoza's arguments for the existence of God. Philosophy and Phenomenological Research 75: 269-297.

MacLean, K. A., Johnson, M. W., Griffiths, R. R. (2011). Mystical experiences occasioned by the hallucinogen Psilocybin Lead to increases in the personality domain of openness. Psychopharmacology (Berl) 25: 1453-1461.

Maimonides, M. (1963). Guide of the Perplexed. Shlomo Pines (trans.). Chicago: University of Chicago Press.

Manson, N. A. (2009). The fine-tuning argument. Philosophy Compass 4: 271-286.

Martin, M. (1990). Atheism: A Philosophical Justification. Philadelphia: Temple University Press.

Matthews, G. B. and Baker, L. R. (2010). The ontological argument simplified. Analysis 70: 210-212.

McBrayer, J. P. (2010). Skeptical theism. Philosophy Compass 5: 611-623.

Miller, C. (2011). Atheism and the benefits of theistic belief. In J. L. Kvanvig (ed.), Oxford Studies in Philosophy of Religion Vol. IV (pp. 99-127). Oxford: Clarendon Press.

Mizrahi, M. (2012). Why the ultimate argument for scientific realism ultimately fails. Studies in History and Philosophy of Science 43: 132-138.

Moretti, L. (forthcoming). Phenomenal conservatism. Analysis.

Nagasawa, Y. (2011). The Existence of God: A Philosophical Introduction. London: Routledge.

Oppy, G. (2006). Arguing about Gods. New York: Cambridge University Press.

Palmer, M. (2001). The Question of God: An Introduction and Sourcebook. London: Routledge.

Persinger, M. A. and Koren, S. (2005). A response to Granqvist et al. Sensed presence and mystical experiences are predicted by suggestibility, not by the application of transcranial weak magnetic fields. Neuroscience Letters 380: 346-347. 
Plantinga, A. (1998). The ontological argument. In J. F. Sennett (ed.), The Analytic Theist: An Alvin Plantinga Reader (pp. 50-71). Grand Rapids: William B. Eerdmans Publishing Co.

Plantinga, A. (2000). Warranted Christian Belief. New York: Oxford University Press.

Pollock, J. L. and Cruz, J. (1999). Contemporary Theories of Knowledge. Lanham, MA: Rowman \& Littlefield.

Psillos, S. (2007). The fine structure of inference to the best explanation. Philosophy and Phenomenological Research 74: 441-448.

Rea, M. and Pojman, L. (2014). Philosophy of Religion: An Anthology. $7^{\text {th }}$ Ed. Stamford, $\mathrm{CT}$ : Cengage Learning.

Richards, H. J. (2000). Philosophy of Religion. $2^{\text {nd }}$ Ed. Oxford: Heinemann.

Ritchie, A. (2012). From Morality to Metaphysics: The Theistic Implications of Our Ethical Commitments. Oxford: Oxford University Press.

Roberts, J. T. (2012). Fine-tuning and the infrared bull's-eye. Philosophical Studies 160: 287-303.

Salmon, M. H. (2013). Introduction to Logic and Critical Thinking. Sixth Edition. Boston, MA: Wadsworth.

Seeskin, K. (2005). Metaphysics and its transcendence. In K. Seeskin (ed.), The Cambridge Companion to Maimonides (pp. 82-104). New York: Cambridge University Press.

Smith, M. (2014). The epistemology of religion. Analysis 74: 135-147.

Sober, E. (1988). Reconstructing the Past: Parsimony, Evolution and Inference. Cambridge, MA: The MIT Press.

Sober, E. (1994). Let's razor Ockham's Razor. In E. Sober (Ed.), From a Biological Point of View (pp. 136-157). Cambridge: Cambridge University Press.

Sober, E. (1998). Simplicity (in scientific theories). In E. Craig (Ed.), Routledge Encyclopedia of Philosophy. London: Routledge.

http://www.rep.routledge.com/article/Q095SECT1.

Swinburne, R. (1979). The Existence of God. Oxford: Clarendon Press.

Tucker, C. (2011). Phenomenal conservatism and evidentialism in religious epistemology. In R. VanArragon and K. Clark (eds.), Evidence and Religious Belief (pp. 52-73). Oxford: Oxford University Press. 
van Inwagen, P. (1995). God, Knowledge, and Mystery. Ithaca: Cornell University Press.

Webb, M. (2011). Religious experience. In E. N. Zalta (Ed.), The Stanford Encyclopedia of Philosophy (Winter 2011 Edition). http://plato.stanford.edu/archives/win2011/entries/religious-experience/.

Wierenga, E. R. (1989). The Nature of God: An Inquiry Into Divine Attributes. Ithaca, NY: Cornell University Press.

Yandell, K. E. (1993). The Epistemology of Religious Experience. New York: Cambridge University Press.

Zahar, E. (1973). Why did Einstein's programme supersede Lorentz's? (I) British Journal for the Philosophy of Science 24: 95-123.

Zahar, E. (1973). Why did Einstein's programme supersede Lorentz's? (II) British Journal for the Philosophy of Science 24: 223-262.

Zagzebski, L. (2011). First person and third person reasons and religious epistemology. European Journal for Philosophy of Religion 3: 285-304. 